\title{
Overview of International Business
}

\author{
Fan Chen \\ International Business School \\ Yunnan University of Finance and Economics \\ Kunming, China \\ 790297074@qq.com \\ Sun Meng* \\ International Business School
}

\author{
University of Finance and Economics \\ Kunming, China \\ 55658741@qq.com (Corresponding author)
}

\author{
Wei Zhou
}

School of Finance

University of Finance and Economics

Kunming, China

zw453@163.com

\begin{abstract}
With the rapid development of econom, science and technology, international business comprises a large and growing portion of the world's total business. The purpose of this paper is mainly to state why we develop international business and how to do international business.
\end{abstract}

Keywords—international business; four main risks; paly home advantages

\section{INTRODUCTION}

To some extent, business, especially international business has much to do with the development, prosperity and fall of a country. The judgment of international business is whether it has kept up with the time and kept connected with the changing outside world, since an old saying goes: Know the enemy and know yourself, and you can fight a hundred battles with no danger of defeat [1].

While international business has been around for centuries, it has gained much speed and complexity over the past two decades, and nowadays, it played an indispensable role in the economic growth[2]. Firms seek international market opportunities more today than ever before, toughing the lives of billions of people around the world. Since China joined the WTO, the economic development entered a new stage and the foreign trade scaled new heights.

\section{THE DEFINITION AND DESCRIPTION OF INTERNATIONAL BUSINESS}

International business refers to any commercial transaction that across the borders of two or more nations. You don't have to set foot outside a small town to find evidence of international business. No matter where you live, you will be surrounded by imports ---goods and services brought into a country that are acquired from organizations located abroad [3]. Your counterparts around the world will undoubtedly spend some part of their day using your nation' $\mathrm{s}$ exports---goods and services produced or based in one country that are sold abroad [4].

While in that definition international business refers to

\footnotetext{
*Corresponding author
}

two aspects, one is the international trade transaction such as the sales of goods and service; the other is the fund transfer as a result of some trade and non-trade transactions such as international lending and investment, international aids and grants, cross-border personal remittances.

\section{WHY PURSUING INTERNATIONAL STRATEGIES?}

\section{A. Seek opportunities for growth through diversification}

Substantial market potential exists outside the home country. Many large and small companies desire more than half of their sales from abroad. When they diversify into foreign markets, firms can generate sales and profit opportunities that can not be matched at home [5]. Internationalization can also extend the marketable life of the product or services that have reached their maturity in the home country.

\section{B. Earn higher margins and profits}

For many types of products and services, market growth in mature economies is sluggish or flat. Competition is often intense, forcing firms to get by on slim profit margins. By contrast, most foreign markets may be underserved or not served at all. Less intense competition, combined with strong market demand, implies that companies can command higher margins for their offerings [6].

\section{Gain new ideas about product, services, and business methods}

International markets are characterized by tough competitors and demanding customer with varies needs. Unique foreign environment expose firms to new ideas for products [7]. The experience of doing business abroad helps the firms acquire new knowledge for improving organizational effectiveness and efficiency.

\section{Gaining access to lower-cost or better-value factors of product}

Internalization enables the firms to access capital, technology, managerial talent, labor, and land at lower cost, higher-quality, or better overall value at locations worldwide. More commonly, firms venture abroad in search of skilled or low-cost labor. 


\section{E. Develop economies of scale in souring, production, marketing}

Economies of scale refer to the reduction of the per-unit cost of manufacturing and marketing due to operating at high volume. By expanding internationally, the firm greatly increases the size of its customer base, thereby increasing the volume of the products that it manufactures. On a per-unite-of-output basis, the greater the volume of production, the lower the total cost.

\section{THE INFLUENCE OF INTERNATIONAL BUSINESS TO CHINA IN DIFFERENT ASPECTS}

International business is not isolated and it has influence on politics, economy, and culture as well. Since China has the largest population in the world, the influence of international business is more obvious [8].

\section{A. Politics}

China is a state of friendship and it does business with most of the countries in the world nowadays. Since joined the WTO in the year of 2001 China has a higher international status and its policies and international business do interact with each other [9]. And the situation of international business can also affect the leading party's decisions of economy policy, environment policy, education policy, and so on [10].

\section{B. Economy}

As to economy, international business is originally economic issues and it surly is connected with China's economy. Not only does international business bring China a large variety of goods rarely seen here, but it also calls for a running service of banks, security, transportation, and so on. Thus science and technology play a more and more vital role in modern society, and we are familiar with the saying: science and technology are the primary productive forces [11]. Meanwhile, it requires a great number of people who have advanced education to work for it. And we college student can find well-paid jobs and a lot of opportunities to start our own career.

\section{Culture}

Finally, in terms of culture, communication has always been the main point of business, no matter international business or domestic business. That is to say that international business is not simple exchanging of the goods, but also the mixture of several different cultures. Language is the tool to do business, and English is one of the official languages of international business [12]. And Chinese students have taken English as a second language since they were in primary school. Most college students can speak fluent English. In the meantime, international business also takes Chinese culture to the western countries because Confucius Institutes develop fast and Chinese food is one of the best choices when western hostess check their food list [13].

\section{THE FOUR RISKS IN INTERNATIONALIZATION}

\section{A. Cross-cultural risks}

Cross-cultural risks refer to a situation or event where a cultural miscommunication puts some human value at stake. Cross-cultural risk is posed by differences in language, lifestyle, mindsets, customs, and religion [14]. Foreign customer characteristics differ significantly from those of buyers in the home market. Language is a critical dimension of culture and people use it to communicate with each other, reflecting people's value systems and living conditions. When translating one language to another, it is often difficult to find words that convey the same meaning. Such challenges impede effective communication and cause misunderstanding [15].

\section{B. Country risk}

Country risk refers to the potentially adverse effect on company operations and profitability caused by development in the political, legal, and economic environment in a foreign country [16]. Country risks include the possibility of foreign government intervention in firms' business activities. For example, government may restrict access to markets, impose bureaucratic procedures on business transactions, and limit the amount of earned income that firms can bring from foreign operations.

\section{Currency risk}

Currency risk also referred to financial risks. It refers to the risk of adverse fluctuations in exchange rates. Fluctuation is common for exchange rates, or then value of one currency in terms of another. Currency risk arises because international transactions are often conducted in more than one national currency. When currencies fluctuate significantly, the value of the firm's assets, earnings, and operating income can be reduced [17]. The cost of importing parts used in manufacturing finished products can increase dramatically if the value of the currency in which the imports are denominated rises sharply.

\section{Commercial risk}

It refers to the firm's potential loss or failure form poorly developed strategies, tactics, or procedures. Managers may make poor choices in such area as the selection of business partners, timing of market entry, pricing. In a foreign market, terminating business partner can prove costly due to regulations that protect local firms.

\section{HOW CHINA ACTVELYPARTICIPATES IN INTERNATIONAL BUSINESS}

\section{A. Accelerate development, promote cooperation, defense risks and implement comprehensive development strategy}

To reform the existing rules of game dominated by developed countries and to establish a new international economic order. China still has a long way to go to strive for more say and decision-making power in international economic affairs. At the same time, our country also needs to cooperate with developing countries and develop their economic and trade relations, which will not only help us consolidate the system and friendship with developing countries, but also promote the establishment of an international economic order. It is conducive to create an external environment helpful for international economic and 
trade cooperation [18].

\section{B. Gradually opening up financial markets to avoid the impact of the financial crisis}

The stability of a country's financial market, to a large extent, is subject to the international economic environment [19]. Although it is difficult to control the disadvantage influences arising from external factors on foreign financial markets, it can play an important role as long as to establish a sound financial system, implement sound macroeconomic policies and financial policies in china, strengthen financial supervision, prevent and control effectively in process of the opening of the financial market in financial risk.

\section{Explore the international market and introduce advanced technology abroad}

China is a developing country, so it needs to pay attention on how to grasp the initiative in the process of participation. Therefore, we should deepen the reform and persist in opening up to the world with a more active attitude, keep a sober mind to take a series of effective measures and opportunities to meet the challenge. Also, it will be very helpful to make full use of international conditions and explore the international market. At the basis of those measures, we can introduce advanced technology abroad so as to promote the country's economic development. In the process of WTO, it is essential to create a good environment for enterprises, after all, the corporations are the key players in the international business [20]. By doing these we can accelerate the economic development, enhance the strength facing of various challenges brought by economic globalization.

\section{CONCLUSIONS}

Competition continues to increase in intensity. Many firms that would not have entered a single country because it lacked sufficient market size have established plants in the comparatively larger trading groups (European Union, ASEAN, and MERCOSUR). The result of this rush to globalization has been an explosive growth in international business.

\section{ACKNOWLEDGMENT}

This work was supported by the Natural Science Foundation of China (No. 71561026); Science Foundation and Major Project of Educational Committee of Yunnan Province (Grant No. 2014Z100), and Philosophy and Social Science Foundation of Yunnan Province (Grant No. YB2015087).

\section{REFERENCES}

[1] P.S. Adler, L.C. Forbes, and H. Willmott, "Critical management studies," The Academy of Management Annals, Vol. 1,Lawrence Erlbaum,Mahwah, 2007, pp. 119-79.

[2] Brandt, Loren and E. Thun, "The Fight for the Middle: Upgrading Competition, and Industrial Development in China," World Development, vol. 38, 2010, pp. 1555-1574.

[3] Breznitz, Dan and M. Michael, "Run of the Red Queen: Government, Innovation,Globalization and Economic Growth in China," New Haven: Yale University Press, p. 210.

[4] Brødsgaard, and K. Erik. "Politics and Business Group Formation in China: TheParty in Control?" China Quarterly, vol. 211, 2010, pp. 624-648.

[5] Caulfield, and L. Janice. "Local Government Reform in China: A Rational ActorPerspective," International Review of Administrative Sciences, vol. 72, 2006, pp. 253-267.

[6] G. Cairns, and J. Roberts, "Introduction from the Editors", critical perspectives oninternational business, vol. 1, 2005, pp. 4-6

[7] T. Devinney, T. Pedersen, and L. Tihanyi, "The Past, Present and Future ofInternational Business and Management, Advancesin International Management," vol. 23, Emerald Group Publishing, Bingley, 2010.

[8] J.H. Dunning, "The study of international business: a plea for a more interdisciplinaryapproach", Journal of International Business Studies, vol. 20, 1989, pp. 411-36.

[9] J. John, L. Kenneth, C.Y. WildandJerry, and Han, "International Business," 2008, p. 27.

[10] M.J. Oesterle, and S. Laudien, "The future of international business research and therelevance gap: a German perspective," European Journal of International Management, vol. 1, 2007, pp. 39-55.

[11] J. Roberts, and T. Fuller, "International business: past, present and futures", Futures, vol. 42, 2010, pp. 901-909.

[12] S. Wall, SonalMinocha and B. Rees, "International business," third edition, 2012, pp. 21.

[13] D.P Sullivan, and J.D. Daniels, "Defining international business through its research," in Buckley, What Is International Business?, Palgrave, London, 2005, pp. 68-84.

[14] C. Tamerl, K. Gary, and K. John, "International Businesss, Strategy, Management, and the New Realities," 2010, pp. 11-12.

[15] S. Werner, "Recent developments in international management research: areview of 20top management journals", Journal of Management, vol. 28, 2002, pp. 277-305.

[16] W. Zhou, and J.M. He. "Generalized GM $(1,1)$ model and its application in forecasting of fuel production," Applied Mathematical Modelling, vol. 37, 2013, pp. 6234-6243.

[17] W. Zhou, and D.M. Zhang. "An improved metabolism grey model for predicting small samples with a singular datum and its application to sulfur dioxide emissions in China," Discrete Dynamics in Nature and Society, 2016, pp. 1-12.

[18] W. Zhou, B.Q. Ding, and Y. Zhang. "The improved grey model by fusing exponential buffer operator and its application," Journal of Intelligent and Fuzzy Systems, 2017. (On line)

[19] W. Zhou, and Z. Xu. "Generalized asymmetric linguistic term set and its application to qualitative decision making involving risk appetites," European Journal of Operational Research, vol. 254, 2016, pp. 610-621.

[20] W. Zhou. "Dynamic and asymmetric contagion reactions of financial markets during the last subprime crisis," Computational Economics, 2016.

[21] W. Zhou, and J. He. "Intuitionistic fuzzy geometric Bonferroni means and their application in multicriteria decision making," International Journal of Intelligent Systems, vol. 27, 2012, pp. 995-101. 